\title{
A Practical Method for the Synthesis of 2-Alkynylpropenals
}

\author{
Charnsak Thongsornkleeb and Rick L. Danheiser ${ }^{*}$ \\ Department of Chemistry, Massachusetts Institute of Technology, Cambridge, Massachusetts \\ 02139
}

\begin{abstract}<smiles>C=C(COCC)COCC(=C)C(=C)C=O</smiles>

A general method for the preparation of 2-alkynyl acroleins is described beginning with vinyl iodide 5 and involving a combination of Sonogashira coupling and Dess-Martin oxidation. Critical to the success of this approach is the use of a special workup procedure for the oxidation step. The resultant enynals participate in a variety of addition reactions including aldol condensations and reactions with organolithium compounds.
\end{abstract}

\begin{abstract}
In connection with our studies on the total synthesis of glycinoeclepin A, we required a practical and efficient method for the preparation of $\alpha, \beta$-unsaturated aldehydes of type 1 bearing alkynyl substituents at the C-2 position (" $\alpha$-alkynyl acroleins"). Remarkably, only one example of the isolation and characterization of an aldehyde of this class has previously been reported in the literature. ${ }^{1}$ Acrolein derivatives of this type are expected to undergo facile dimerization via hetero-Diels-Alder [4+2] cycloaddition, 2,3 and also should be exceptionally prone to polymerization via radical pathways and in the presence of nucleophiles. On the other hand, the multiple functional groups incorporated in these compounds suggest that they should serve as valuable synthetic building blocks in a number of applications. Unfortunately, the anticipated sensitivity of these enynals limits the range of methods potentially applicable for their preparation, and to date the synthetic utility of this class of aldehydes remains unrealized. 4
\end{abstract}

(C) 2005 American Chemical Society

danheisr@mit.edu.

Supporting Information Available: Experimental procedures and characterization data for compounds $\mathbf{7 c , d}, \mathbf{1 b}-\mathbf{d}$, and $\mathbf{9 b}-\mathbf{d}$ and ${ }^{1} \mathrm{H}$ NMR spectra for compounds $\mathbf{1 a - d}, \mathbf{7 b}-\mathbf{d}, \mathbf{9 a}-\mathbf{d}$, and 10-12. This material is available free of charge via the Internet at http://pubs.acs.org. 


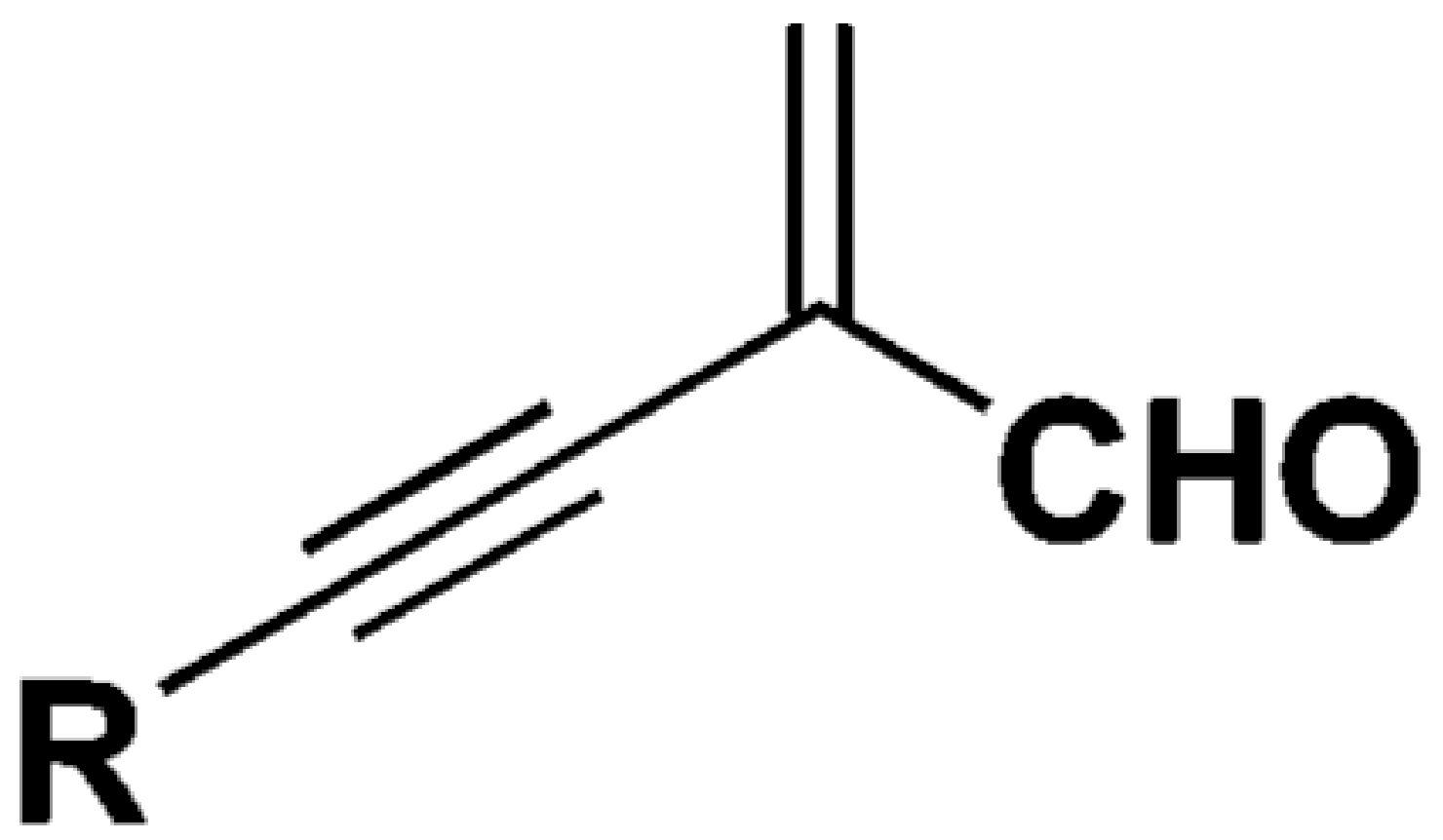

In 2000, Funk and co-workers described an ingenious method for the in situ generation of sensitive 2-substituted acroleins involving the thermal [4+2] cycloreversion of 5-substituted $4 H$-1,3-dioxins. ${ }^{5}$ Attempted application of this protocol to the preparation of a 2-alkynyl acrolein derivative led only to the isolation of the corresponding hetero-Diels-Alder dimer, but the unstable enynal could be trapped in situ by carrying out the thermolysis in the presence of excess Danishefsky's diene (eq 1). ${ }^{5}$ Unfortunately, these conditions are not compatible with our projected use of 2-alkynylpropenals, which involves aldol condensation of the aldehydes at low temperature with lithium enolates. The elevated temperatures required in the Funk protocol, as well as the fact that 1 equiv of acetone is generated as a byproduct of the retroDiels-Alder reaction, obviously set severe constraints on the range of applications possible for 2-alkynyl acroleins produced under these conditions. We therefore undertook an investigation of alternative methods for the preparation of these $\alpha, \beta$-unsaturated aldehydes that would be compatible with a broader range of subsequent transformations. 


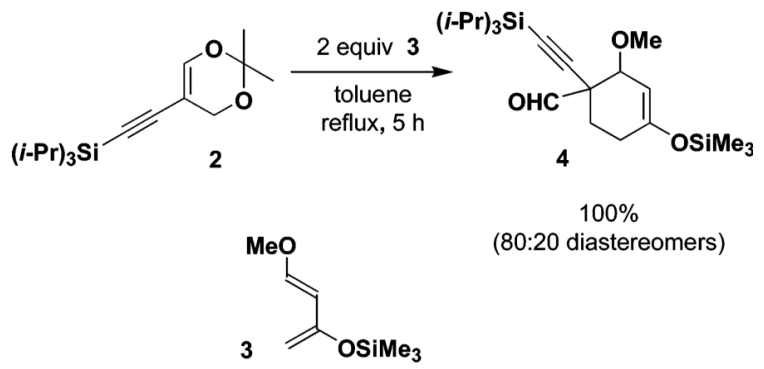

Scheme 1 outlines our approach to the synthesis of 2-alkynylpropenals. Sonogashira coupling ${ }^{6}$ of 2-iodo-2-propenol ${ }^{7}(5)$ with a wide range of acetylenes was expected to provide convenient access to enynyl alcohols of type 7,8 which would then be oxidized to furnish the desired aldehydes. In the event, standard oxidation protocols provided the unstable acroleins in poor yield due to the propensity of these $\alpha, \beta$-unsaturated aldehydes to undergo Diels-Alder dimerization and polymerization. Success was finally achieved by employing a modified DessMartin oxidation 9,10 protocol, which avoids an aqueous workup procedure. A stratagem for precipitating iodinane byproducts by diluting with pentane was introduced recently by Wavrin and Viala, ${ }^{11}$ and we found that with some modification this protocol can be employed for the efficient formation of highly sensitive 2-alkynylpropenals. Specifically, oxidation is first carried out using 1.1-1.3 equiv of Dess-Martin periodinane in $\mathrm{CH}_{2} \mathrm{Cl}_{2}$ at $0{ }^{\circ} \mathrm{C}$. The reaction mixture is then cooled to $-78^{\circ} \mathrm{C}$ and diluted with an equal volume of pentane, and then excess poly(4-vinylpyridine) is added to sequester the acetic acid generated in the reaction. The reaction mixture is filtered under a positive pressure of argon through a jacketed plug of silica gel cooled at $-78^{\circ} \mathrm{C}$, and then concentrated with the aid of toluene to remove remaining traces of acetic acid via azeotropic distillation. Final concentration to dryness is conducted at 0.05 $\mathrm{mmHg}$ and $-78{ }^{\circ} \mathrm{C}$. The desired aldehydes 1a-d are obtained in $41-78 \%$ overall yield and in greater than $95 \%$ purity as determined by IR and ${ }^{1} \mathrm{H}$ NMR analysis.

As expected, 2-alkynylpropenals 1a-d readily undergo dimerization via hetero-Diels-Alder cycloaddition. For example, NMR analysis of a solution of aldehyde $1 \mathbf{a}$ in $\mathrm{CDCl}_{3}(0.4 \mathrm{M})$ showed traces of dimer formation within minutes at room temperature, and after standing overnight, more than half of the starting material was converted to the hetero-Diels-Alder cycloadduct 8 . On the other hand, the 2-alkynyl $\alpha, \beta$-unsaturated aldehydes produced in this fashion can be taken up in THF and employed in a number of subsequent useful synthetic transformations. For example, aldol condensation with the lithium enolate derivative of pinacolone provides the desired $\beta$-hydroxy ketones $\mathbf{9 a - d}$ in good to excellent yield (eq 3).

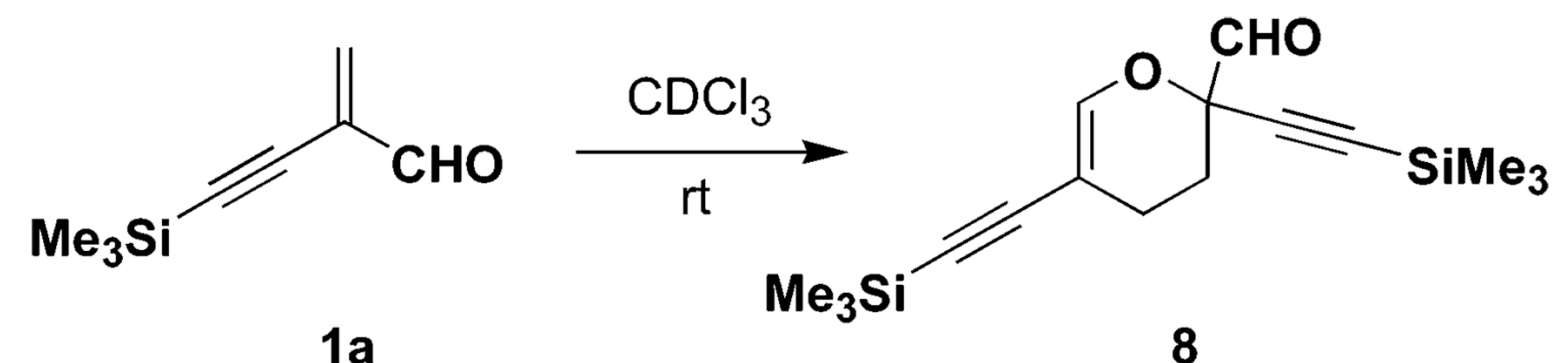



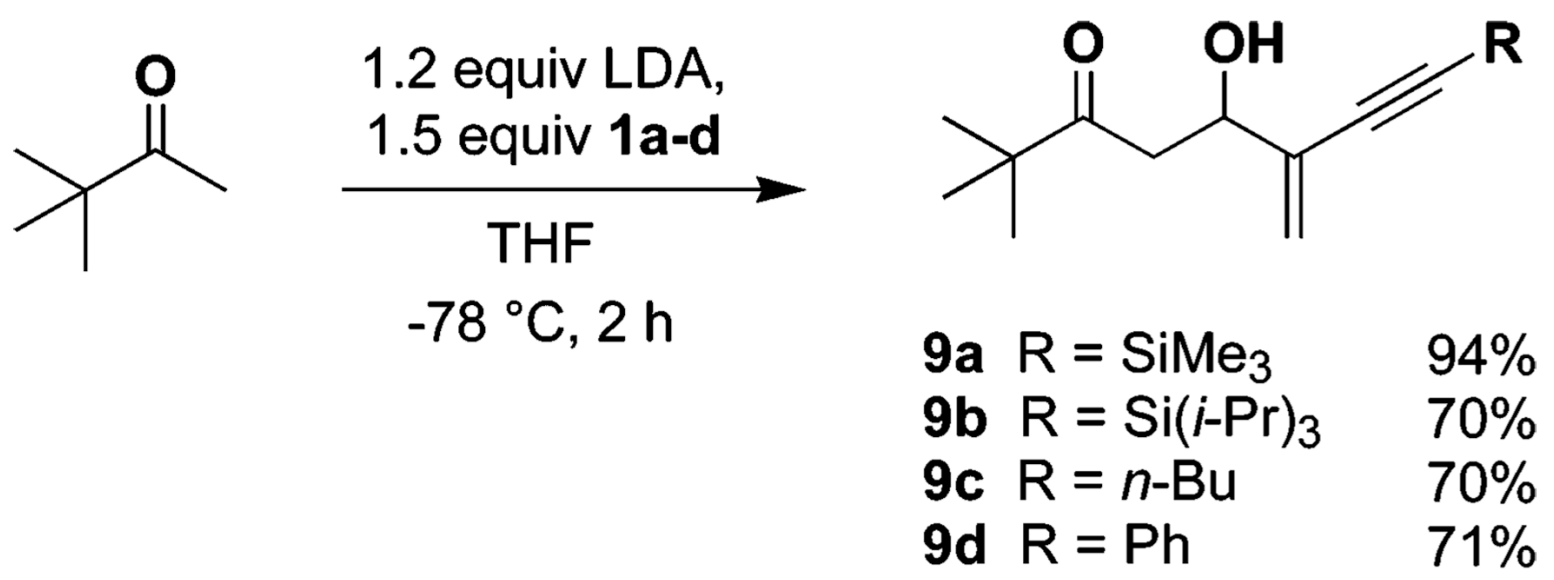

(3)

In a similar fashion, addition of organo- and alkynyl-lithium compounds proceeds smoothly as outlined in Scheme 2 to furnish the expected enynyl alcohols $\mathbf{1 0}$ and $\mathbf{1 1}$ in good overall yield from 7a, the precursor to the alkynyl acrolein. Moderately stabilized organolithium compounds react in a like manner. For example, addition of the lithium derivative of methyl phenyl sulfone to enynal 1a occurs smoothly to afford the expected $\beta$-hydroxy sulfone $\mathbf{1 2}$ in $61 \%$ yield (eq 4).

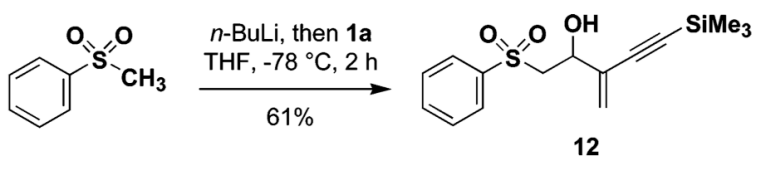

In summary, the combination of Sonogashira coupling and Dess-Martin oxidation provides a convenient method for the preparation of a wide range of 2-alkynyl acroleins. Critical to the success of this approach is the use of a modified workup procedure for the oxidation step, in which byproducts are separated by precipitation with pentane, trapping with poly(4vinylpyridine), and azeotropic distillation with toluene.

\section{Experimental Section}

General Procedure for the Preparation of Enynyl Alcohols: 2-Methylene-4-(triisopropylsilyl) but-3-yn-1-ol (7b)

A 50-mL, one-necked, round-bottomed flask fitted with a rubber septum and argon inlet needle was charged with $\left(\mathrm{Ph}_{3} \mathrm{P}\right)_{4} \mathrm{Pd}(0.089 \mathrm{~g}, 0.077 \mathrm{mmol}), \mathrm{CuI}(0.042 \mathrm{~g}, 0.22 \mathrm{mmol})$, and $10 \mathrm{~mL}$ of THF. A solution of the vinyl iodide $5(0.464 \mathrm{~g}, 2.52 \mathrm{mmol})$ in $3 \mathrm{~mL}$ of THF was added via cannula over $2 \mathrm{~min}$ (the flask was rinsed with $2 \mathrm{~mL}$ of THF) and triethylamine $(0.46 \mathrm{~mL}, 0.33$ $\mathrm{g}, 3.28 \mathrm{mmol}$ ) was then added via syringe over $30 \mathrm{~s}$. The resulting yellow mixture was stirred at room temperature for $3 \mathrm{~min}$, and then (triisopropylsilyl)acetylene $(0.74 \mathrm{~mL}, 0.60 \mathrm{~g}, 3.28$ $\mathrm{mmol}$ ) was added via syringe over $2 \mathrm{~min}$. The reaction mixture was stirred at room temperature for $11.5 \mathrm{~h}$ and then heated at reflux for $9 \mathrm{~h}$. The reaction mixture was allowed to cool to room temperature and then filtered through $10 \mathrm{~g}$ of silica gel with the aid of three $15-\mathrm{mL}$ portions of $\mathrm{Et}_{2} \mathrm{O}$. Concentration of the filtrate afforded $0.689 \mathrm{~g}$ of a brown oil. Column chromatography 
on $35 \mathrm{~g}$ of silica gel (gradient elution with 0-10\% EtOAc-hexane) provided $0.336 \mathrm{~g}(56 \%)$ of enyne 7b as a yellow oil: IR (film) 3356, 2942, 2865, 2145, and $1617 \mathrm{~cm}^{-1} ;{ }^{1} \mathrm{H}$ NMR (500 $\left.\mathrm{MHz}, \mathrm{CDCl}_{3}\right) \delta 5.54(\mathrm{dd}, J=1.5,10.5 \mathrm{~Hz}, 2 \mathrm{H}), 4.12(\mathrm{td}, J=1.5,7.0 \mathrm{~Hz}, 2 \mathrm{H}), 1.68(\mathrm{dt}, J=$ $1.5,7.0 \mathrm{~Hz}, 1 \mathrm{H})$, and $1.09($ app s, $21 \mathrm{H}) ;{ }^{13} \mathrm{C} \mathrm{NMR}\left(125 \mathrm{MHz}, \mathrm{CDCl}_{3}\right) \delta 131.7,120.8,104.7$, 93.0, 65.5, 18.8, and 11.4; HRMS-EI $\mathrm{m} / z[\mathrm{M}]^{+}$calcd for $\mathrm{C}_{14} \mathrm{H}_{26} \mathrm{OSi} 238.1747$, found 238.1741.

\section{General Procedure for the Oxidation of Allylic Alcohols to Enynyl Aldehydes: 2-Methylene-4- (trimethylsilyl)but-3-ynal (1a)}

A 50-mL, two-necked, pear-shaped flask fitted with an argon inlet adapter and a rubber septum was charged with a solution of the allylic alcohol $7 \mathbf{a}(0.942 \mathrm{~g}, 6.11 \mathrm{mmol})$ in $30 \mathrm{~mL}$ of dichloromethane and cooled at $0{ }^{\circ} \mathrm{C}$ while Dess-Martin periodinane $(2.856 \mathrm{~g}, 6.73 \mathrm{mmol})$ was added in one portion. The heterogeneous reaction mixture was stirred at $0{ }^{\circ} \mathrm{C}$ for $5 \mathrm{~min}$ and then allowed to warm to room temperature. After $20 \mathrm{~min}$, the reaction mixture was cooled to $-78^{\circ} \mathrm{C}$ and diluted with $30 \mathrm{~mL}$ of pentane, poly(4-vinylpyridine) $(3.227 \mathrm{~g}, 30.69 \mathrm{mmol})$ was added in one portion, and the resulting mixture was stirred at $-78{ }^{\circ} \mathrm{C}$ for $25 \mathrm{~min}$. A $2.5-\mathrm{cm}$ diameter jacketed column fitted with a rubber septum at the top and a short needle at the bottom was charged with a $6-\mathrm{cm}$ plug of silica gel, which was cooled at $-78^{\circ} \mathrm{C}$ by filling the jacket with dry ice-acetone. The reaction mixture was transferred into the column by cannula and filtered through the silica gel under a positive pressure of argon into a $200-\mathrm{mL}$ recovery flask fitted with a rubber septum with a short needle as vent. The reaction flask and the column were rinsed with four $15-\mathrm{mL}$ portions of 4:1 pentane-ether. The filtrate was concentrated by rotary evaporation at $25^{\circ} \mathrm{C}(20 \mathrm{mmHg})$ to a volume of ca. $3 \mathrm{~mL}$ and this solution was then cooled to $-78^{\circ} \mathrm{C}$ and diluted with $5 \mathrm{~mL}$ of toluene. The resulting solution was concentrated by rotary evaporation at $25^{\circ} \mathrm{C}$ to a volume of ca. $3 \mathrm{~mL}$ and the resulting pale yellow solution was cooled to $-78{ }^{\circ} \mathrm{C}$ and further concentrated at $0.05 \mathrm{mmHg}$ (ca. $15 \mathrm{~min}$ ) to furnish aldehyde 1a as a yellow oil. For spectroscopic analysis, this material was dissolved in ca. $1 \mathrm{~mL}$ of $\mathrm{CDCl}_{3}$ and 4-isopropylbenzaldehyde $(0.92 \mathrm{~mL}, 0.90 \mathrm{~g}, 6.1 \mathrm{mmol})$ was added as an internal standard. The resulting solution was transferred to an NMR tube via cannula under a positive pressure of argon. The yield of aldehyde 1a was determined by ${ }^{1} \mathrm{H}$ NMR analysis to be $52 \%$ : IR (film) 2960, 2928, 2144, 1749, and $1624 \mathrm{~cm}^{-1} ;{ }^{1} \mathrm{H}$ NMR $\left(500 \mathrm{MHz}, \mathrm{CDCl}_{3}\right) \delta 9.48(\mathrm{~s}, 1 \mathrm{H}), 6.63(\mathrm{~d}$, $J=1.5 \mathrm{~Hz}, 1 \mathrm{H}), 6.40(\mathrm{~d}, J=1.5 \mathrm{~Hz}, 1 \mathrm{H})$, and $0.25(\mathrm{~s}, 1 \mathrm{H}) ;{ }^{13} \mathrm{C} \mathrm{NMR}\left(125 \mathrm{MHz}, \mathrm{CDCl}_{3}\right) \delta$ $190.0,139.6,133.1,101.8,97.5$, and -0.1 .

\section{General Procedure for the Aldol Reaction of Enynyl Aldehydes: 5-Hydroxy-2,2-dimethyl-6- methylene-8-(trimethylsilyl) oct-7-yn-3-one (9a)}

A 25-mL, two-necked, round-bottomed flask fitted with an argon inlet adapter and a rubber septum was charged with $12 \mathrm{~mL}$ of THF and diisopropylamine $(0.19 \mathrm{~mL}, 0.13 \mathrm{~g}, 1.3 \mathrm{mmol})$ and cooled at $0{ }^{\circ} \mathrm{C}$ while $0.50 \mathrm{~mL}$ of $\mathrm{n}$-BuLi solution $(2.41 \mathrm{M}$ in hexane, $1.2 \mathrm{mmol}$ ) was added dropwise via syringe over $30 \mathrm{~s}$. The resulting yellow solution was stirred at $0{ }^{\circ} \mathrm{C}$ for $15 \mathrm{~min}$ and then cooled to $-78^{\circ} \mathrm{C}$.

A 10-mL, one-necked, pear-shaped flask was charged with $1.5 \mathrm{~mL}$ of THF and pinacolone $(0.12 \mathrm{~mL}, 0.10 \mathrm{~g}, 1.0 \mathrm{mmol})$ and cooled to $-78^{\circ} \mathrm{C}$. The resulting solution was transferred to the solution of LDA via cannula over $3 \mathrm{~min}$ (the flask was rinsed with $0.5 \mathrm{~mL}$ of THF) and the resulting cloudy pale-yellow mixture was stirred at $-78^{\circ} \mathrm{C}$ for $2 \mathrm{~h}$.

Oxidation of allylic alcohol 7a $(0.423 \mathrm{~g}, 2.74 \mathrm{mmol})$ with Dess-Martin periodinane $(1.284 \mathrm{~g}$, $3.027 \mathrm{mmol}$ ) in $27 \mathrm{~mL}$ of $\mathrm{CH}_{2} \mathrm{Cl}_{2}$ was carried out according to the General Procedure to furnish aldehyde 1a (estimated yield of $1.5 \mathrm{mmol}$ based on previous experiments). This material (not allowed to warm above $-78^{\circ} \mathrm{C}$ once solvent was removed) was dissolved in $3 \mathrm{~mL}$ of THF and then transferred via cannula over $2 \mathrm{~min}$ into the solution of lithium enolate prepared as described above. The resulting clear, yellow solution was stirred at $-78^{\circ} \mathrm{C}$ for $2 \mathrm{~h}$ and then 
treated dropwise with $1 \mathrm{~mL}$ of half-saturated aq $\mathrm{NH}_{4} \mathrm{Cl}$ solution (pre-cooled at $0{ }^{\circ} \mathrm{C}$ ). The resulting mixture was diluted with $15 \mathrm{~mL}$ of $\mathrm{Et}_{2} \mathrm{O}$ and $10 \mathrm{~mL}$ of water, and the aqueous phase was separated and extracted with three 7-mL portions of $\mathrm{Et}_{2} \mathrm{O}$. The combined organic phases were washed with $20 \mathrm{~mL}$ of saturated $\mathrm{NaCl}$ solution, dried over $\mathrm{MgSO}_{4}$, filtered, and concentrated to afford $0.406 \mathrm{~g}$ of a yellow oil. Column chromatography on $20 \mathrm{~g}$ of silica gel (gradient elution with 0-10\% EtOAc-hexane) afforded $0.242 \mathrm{~g}(94 \%)$ of 9a as a pale yellow oil: IR (film) 3473, 2964, 2906, 2873, 2143, 1705, and $1625 \mathrm{~cm}^{-1}$; ${ }^{1} \mathrm{H}$ NMR (500 MHz, $\left.\mathrm{CDCl}_{3}\right) \delta 5.69(\mathrm{t}, J=1.5 \mathrm{~Hz}, 1 \mathrm{H}), 5.55(\mathrm{t}, J=1.5 \mathrm{~Hz}, 1 \mathrm{H}), 4.50-4.52(\mathrm{~m}, 1 \mathrm{H}), 3.51(\mathrm{~d}, J=5.0$ $\mathrm{Hz}, 1 \mathrm{H}), 3.02(\mathrm{dd}, J=3.0,17.5 \mathrm{~Hz}, 1 \mathrm{H}), 2.79(\mathrm{dd}, J=8.5,17.5 \mathrm{~Hz}, 1 \mathrm{H}), 1.16(\mathrm{~s}, 9 \mathrm{H})$, and 0.20 (s, 9H); ${ }^{13} \mathrm{C}$ NMR $\left(125 \mathrm{MHz}, \mathrm{CDCl}_{3}\right) \delta 217.3,132.8,122.1,103.0,96.9,70.0,44.7,41.9,26.3$, and 0.1; HRMS-ESI $m / z[\mathrm{M}+\mathrm{H}]^{+}$calcd for $\mathrm{C}_{14} \mathrm{H}_{24} \mathrm{O}_{2} \mathrm{Si} 253.1618$, found 253.1625.

\section{1,6-Bis(trimethylsilyl)-3-hydroxy-4-methylenehexa-1,5-diyne (10)}

A 50-mL, two-necked, round-bottomed flask fitted with an argon inlet adapter and rubber septum was charged with $12 \mathrm{~mL}$ of THF and trimethylsilylacetylene $(0.26 \mathrm{~mL}, 0.182 \mathrm{~g}, 1.85$ mmol) and cooled at $-78{ }^{\circ} \mathrm{C}$ while $0.67 \mathrm{~mL}$ of $n$-BuLi solution $(2.50 \mathrm{M}$ in hexane, $1.68 \mathrm{mmol}$ ) was added dropwise via syringe over $30 \mathrm{~s}$. The resulting pale yellow solution was stirred at $-78^{\circ} \mathrm{C}$ for $1 \mathrm{~h}$.

Oxidation of allylic alcohol 7a $(0.129 \mathrm{~g}, 0.84 \mathrm{mmol})$ with Dess-Martin periodinane $(0.394 \mathrm{~g}$, $0.92 \mathrm{mmol}$ ) in $4 \mathrm{~mL}$ of $\mathrm{CH}_{2} \mathrm{Cl}_{2}$ was carried out according to the General Procedure to furnish aldehyde 1a (estimated yield of $0.44 \mathrm{mmol}$ based on previous experiments). This material (not allowed to warm above $-78^{\circ} \mathrm{C}$ once solvent was removed) was dissolved in $3 \mathrm{~mL}$ of THF, and then transferred via cannula over 3 min into the solution of lithium (trimethylsilyl)acetylide prepared as described above. The resulting clear yellow solution was allowed to stir at $-78^{\circ}$ $\mathrm{C}$ for $15 \mathrm{~min}$ and then treated with $5 \mathrm{~mL}$ of saturated aq $\mathrm{NH}_{4} \mathrm{Cl}$ solution. The resulting mixture was diluted with $10 \mathrm{~mL}$ of $\mathrm{Et}_{2} \mathrm{O}$ and $5 \mathrm{~mL}$ of water, and the aqueous phase was separated and extracted with three 10-mL portions of $\mathrm{Et}_{2} \mathrm{O}$. The combined organic phases were washed with $20 \mathrm{~mL}$ of saturated $\mathrm{NaCl}$ solution, dried over $\mathrm{MgSO}_{4}$, filtered, and concentrated to afford 0.118 $\mathrm{g}$ of yellow oil. Column chromatography on $15 \mathrm{~g}$ of silica gel (gradient elution with $0-5 \%$ EtOAc-hexane) afforded $0.081 \mathrm{~g}(38 \%$ overall from 7a) of alcohol $\mathbf{1 0}$ as a pale yellow oil: IR (film) 3356, 2961, 2178, 2149, and $1616 \mathrm{~cm}^{-1} ;{ }^{1} \mathrm{H} \mathrm{NMR}\left(500 \mathrm{MHz}, \mathrm{CDCl}_{3}\right) \delta 5.74(\mathrm{t}, J=1.5$ $\mathrm{Hz}, 1 \mathrm{H}), 5.59(\mathrm{t}, J=1.5 \mathrm{~Hz}, 1 \mathrm{H}), 4.84(\mathrm{dt}, J=1.0,7.5 \mathrm{~Hz}, 1 \mathrm{H}), 2.23(\mathrm{~d}, J=2.0 \mathrm{~Hz}, 1 \mathrm{H}), 0.22$ (s, 9H), and $0.20(\mathrm{~s}, 9 \mathrm{H}) ;{ }^{13} \mathrm{C} \mathrm{NMR}\left(125 \mathrm{MHz}, \mathrm{CDCl}_{3}\right) \delta 131.4,123.1,103.1,101.6,97.7$, 91.9, 65.3, 0.05, and -0.04; HRMS-ESI $m / z[\mathrm{M}+\mathrm{Na}]^{+}$calcd for $\mathrm{C}_{13} \mathrm{H}_{22} \mathrm{OSi}_{2} 273.1101$, found 273.1107 .

\section{1-Phenyl-1-hydroxy-2-methylene-4-(trimethylsilyl)-3-butyne (11)}

A 50-mL, two-necked, round-bottomed flask fitted with an argon inlet adapter and a rubber septum was charged with $30 \mathrm{~mL}$ of THF and $1.24 \mathrm{~mL}$ of PhLi solution (1.80 M in hexane, 2.23 mmol) and cooled at $-78{ }^{\circ} \mathrm{C}$.

Oxidation of allylic alcohol 7a $(0.149 \mathrm{~g}, 0.97 \mathrm{mmol})$ with Dess-Martin periodinane $(0.459 \mathrm{~g}$, $1.07 \mathrm{mmol}$ ) in $5 \mathrm{~mL}$ of $\mathrm{CH}_{2} \mathrm{Cl}_{2}$ was carried out according to the General Procedure to furnish aldehyde 1a (estimated yield of $1.0 \mathrm{mmol}$ based on previous experiments). This material (not allowed to warm above $-78{ }^{\circ} \mathrm{C}$ once solvent was removed) was dissolved in $3 \mathrm{~mL}$ of THF, and then transferred via cannula over 3 min into the solution of PhLi described above. The resulting clear yellow solution was allowed to stir at $-78^{\circ} \mathrm{C}$ for $1 \mathrm{~h}$ and then treated dropwise with $5 \mathrm{~mL}$ of saturated aq $\mathrm{NH}_{4} \mathrm{Cl}$ solution. The resulting mixture was diluted with $10 \mathrm{~mL}$ of $\mathrm{Et}_{2} \mathrm{O}$ and $5 \mathrm{~mL}$ of water, and the aqueous phase was separated and extracted with three $10-\mathrm{mL}$ portions of $\mathrm{Et}_{2} \mathrm{O}$. The combined organic phases were washed with $20 \mathrm{~mL}$ of saturated $\mathrm{NaCl}$ solution, dried over $\mathrm{MgSO}_{4}$, filtered, and concentrated to afford $0.249 \mathrm{~g}$ of yellow oil. Column 
chromatography on $25 \mathrm{~g}$ of silica gel (gradient elution with 0-5\% EtOAc-hexane) afforded $0.089 \mathrm{~g}$ ( $40 \%$ overall from 7a) of alcohol $\mathbf{1 1}$ as a pale yellow oil: IR (film) 3385, 3088, 3065, 3031 , and $2146 \mathrm{~cm}^{-1} ;{ }^{1} \mathrm{H}$ NMR $\left(500 \mathrm{MHz}, \mathrm{CDCl}_{3}\right) \delta 7.41-7.43(\mathrm{~m}, 2 \mathrm{H}), 7.34-7.38(\mathrm{~m}, 2 \mathrm{H})$, $7.31(\mathrm{tt}, J=2.5,7.0 \mathrm{~Hz}, 1 \mathrm{H}), 5.63(\mathrm{t}, J=1.5 \mathrm{~Hz}, 1 \mathrm{H}), 5.57(\mathrm{dd}, J=1.0,1.5 \mathrm{~Hz}, 1 \mathrm{H}), 5.22(\mathrm{~d}$, $J=5.0 \mathrm{~Hz}, 1 \mathrm{H}), 2.29(\mathrm{~d}, J=5.0 \mathrm{~Hz}, 1 \mathrm{H})$, and $0.14(\mathrm{~s}, 9 \mathrm{H}) ;{ }^{13} \mathrm{C} \mathrm{NMR}\left(125 \mathrm{MHz}, \mathrm{CDCl}_{3}\right) \delta$ $141.4,134.4,128.5,128.1,126.8,121.9,102.6,98.0,76.4$, and -0.04 ; HRMS-ESI $\mathrm{m} / z$ [M + $\mathrm{Na}]^{+}$calcd for $\mathrm{C}_{14} \mathrm{H}_{18} \mathrm{OSi} 253.1019$, found 253.1024.

\section{1-Phenylsulfonyl-2-hydroxy-3-methylene-5-(trimethylsilyl)-4-pentyne (12)}

A 25-mL, two-necked, round-bottomed flask fitted with an argon inlet adapter and a rubber septum was charged with phenyl methyl sulfone $(0.095 \mathrm{~g}, 0.60 \mathrm{mmol})$ and $5 \mathrm{~mL}$ of THF and cooled at $-78{ }^{\circ} \mathrm{C}$ while $0.28 \mathrm{~mL}$ of $n$-BuLi solution $(2.40 \mathrm{M}$ in hexane, $0.67 \mathrm{mmol})$ was added dropwise via syringe over $30 \mathrm{~s}$. The resulting yellow solution was stirred at $-78^{\circ} \mathrm{C}$ for $1 \mathrm{~h}$.

Oxidation of allylic alcohol 7a $(0.198 \mathrm{~g}, 1.28 \mathrm{mmol})$ with Dess-Martin periodinane $(0.659 \mathrm{~g}$, $1.54 \mathrm{mmol}$ ) in $5 \mathrm{~mL}$ of $\mathrm{CH}_{2} \mathrm{Cl}_{2}$ was carried out according to the General Procedure to furnish aldehyde 1a (estimated yield of $0.7 \mathrm{mmol}$ based on previous experiments). This material (not allowed to warm above $-78{ }^{\circ} \mathrm{C}$ once solvent was removed) was dissolved in $3 \mathrm{~mL}$ of THF, and then transferred via cannula over $5 \mathrm{~min}$ into the solution of lithiated sulfone prepared as described above. The resulting clear yellow solution was allowed to stir at $-78{ }^{\circ} \mathrm{C}$ for $1.7 \mathrm{~h}$ and then treated dropwise with $10 \mathrm{~mL}$ of half-saturated aq $\mathrm{NH}_{4} \mathrm{Cl}$ solution (pre-cooled at $0^{\circ}$ C). The resulting mixture was allowed to warm to room temperature over $15 \mathrm{~min}$ and then diluted with $15 \mathrm{~mL}$ of $\mathrm{Et}_{2} \mathrm{O}$ and $10 \mathrm{~mL}$ of water. The aqueous phase was separated and extracted with four 10-mL portions of $\mathrm{Et}_{2} \mathrm{O}$, and the combined organic phases were washed with $30 \mathrm{~mL}$ of saturated $\mathrm{NaCl}$ solution, dried over $\mathrm{MgSO}_{4}$, filtered, and concentrated to afford $0.248 \mathrm{~g}$ of an orange-yellow oil. Column chromatography on $13 \mathrm{~g}$ of silica gel (gradient elution with 10$40 \%$ EtOAc-hexane) afforded $0.114 \mathrm{~g}(61 \%)$ of alcohol 12 as a white solid: $\mathrm{mp} 122-123{ }^{\circ} \mathrm{C}$; IR (film) 3492, 3067, 2960, 2147, and $1307 \mathrm{~cm}^{-1} ;{ }^{1} \mathrm{H}$ NMR (500 MHz, $\left.\mathrm{CDCl}_{3}\right) \delta$ 7.95-7.98 $(\mathrm{m}, 2 \mathrm{H}), 7.71(\mathrm{tt}, J=1.5,8.0 \mathrm{~Hz}, 1 \mathrm{H}), 7.60-7.63(\mathrm{~m}, 2 \mathrm{H}), 5.72(\mathrm{t}, J=1.5 \mathrm{~Hz}, 1 \mathrm{H}), 5.56(\mathrm{t}, J$ $=1.0 \mathrm{~Hz}, 1 \mathrm{H}), 4.54-4.58(\mathrm{~m}, 1 \mathrm{H}), 3.61(\mathrm{dd}, J=2.0,14.5 \mathrm{~Hz}, 1 \mathrm{H}), 3.46(\mathrm{~d}, J=3.0 \mathrm{~Hz}, 1 \mathrm{H})$, $3.31(\mathrm{dd}, J=9.5,15.0 \mathrm{~Hz}, 1 \mathrm{H})$, and $0.14(\mathrm{~s}, 9 \mathrm{H}) ;{ }^{13} \mathrm{C} \mathrm{NMR}\left(125 \mathrm{MHz}, \mathrm{CDCl}_{3}\right) \delta 139.1,134.3$, $130.5,129.6,128.2,123.2,101.4,97.9,68.4,61.2$, and -0.07 ; HRMS-ESI $m / z[\mathrm{M}+\mathrm{Na}]^{+}$calcd for $\mathrm{C}_{15} \mathrm{H}_{20} \mathrm{O}_{3} \mathrm{SSi} 331.0795$, found 331.0801.

\section{Supplementary Material}

Refer to Web version on PubMed Central for supplementary material.

\section{Acknowledgments}

We thank the National Institutes of Health (GM 28273), Pharmacia, and Merck Research Laboratories for generous financial support. C.T. was supported in part by The Institute for the Promotion of Teaching Science and Technology, Thailand.

\section{References}

1. Dreiding has reported that vapor phase pyrolysis of propargyl propiolate at $500{ }^{\circ} \mathrm{C}$ affords a complex mixture of products from which 2-ethynylpropenal was isolated in $12 \%$ yield. See: Bilinski V, Dreiding AS, Hollenstein H. Helv. Chim. Acta 1983;66:2322.

2. For reviews of the hetero-Diels-Alder reaction, see: (a) Tietze LF, Kettschau G. Top. Curr. Chem 1997;189:1. (b) Boger, DL; Weinreb, SM. Hetero Diels-Alder Methodology in Organic Synthesis. San Diego, CA: Academic Press; 1987.

3. For examples, see: (a) Schulz H, Wagner H. Angew. Chem 1950;29:105. (b) Laitalainen T, Kuronen P, Hesso A. Org. Prep. Proced. Int 1993;25:597. 
4. For a review of methods for the synthesis of acrolein and its $\alpha$-substituted derivatives, see: Keiko NA, Voronkov MG. Russ. Chem. Rev 1993;62:751.

5. Fearnley SP, Funk RL, Gregg RJ. Tetrahedron 2000;56:10275.

6. For recent reviews on palladium-catalyzed alkynylation, see: (a) Sonogashira, K. Sonogashira Alkyne Synthesis. In: Negishi, E.; de Meijere, A., editors. Handbook of Organopalladium Chemistry for Organic Synthesis. Vol. Vol. I. New York: Wiley-Interscience; 2002. p. 493 (b) Negishi, E.; Xu, C. Palladium-Catalyzed Alkynylation with Alkynylmetals and Alkynyl Electrophiles. In: Negishi, E.; de Meijere, A., editors. Handbook of Organopalladium Chemistry for Organic Synthesis. Vol. Vol. I.

New York: Wiley-Interscience; 2002. p. 531 (c) Negishi E, Anastasia L. Chem. Rev 2003;103:1979. [PubMed: 12744698]

7. Available by reaction of propargyl alcohol with chlorotrimethylsilane and sodium iodide according to the procedure of: Kamiya N, Chikami Y, Ishii Y. Synlett 1990:675.

8. Nicolaou has reported that Sonogashira coupling of (trimethylsilyl) acetylene with $\mathbf{5}$ furnishes $\mathbf{7 a}$ in near quantitative yield. See: Nicolaou KC, Koide K. Tetrahedron Lett 1997;38:3667.

9. (a) Dess DB, Martin JC. J. Org. Chem 1983;48:4155. (b) Dess DB, Martin JC. J. Am. Chem. Soc 1991;113:7277.

10. For reviews of oxidations using the Dess-Martin periodinane, see: (a) Boeckman, RK.; Shao, P.; Mullins, JJ. Organic Syntheses. Vol. Vol. X. New York: Wiley \& Sons; 2004. p. 696Collect (b) Tohma H, Kita Y. Adv. Synth. Catal 2004;346:111.

11. Wavrin L, Viala J. Synthesis 2002:326. 

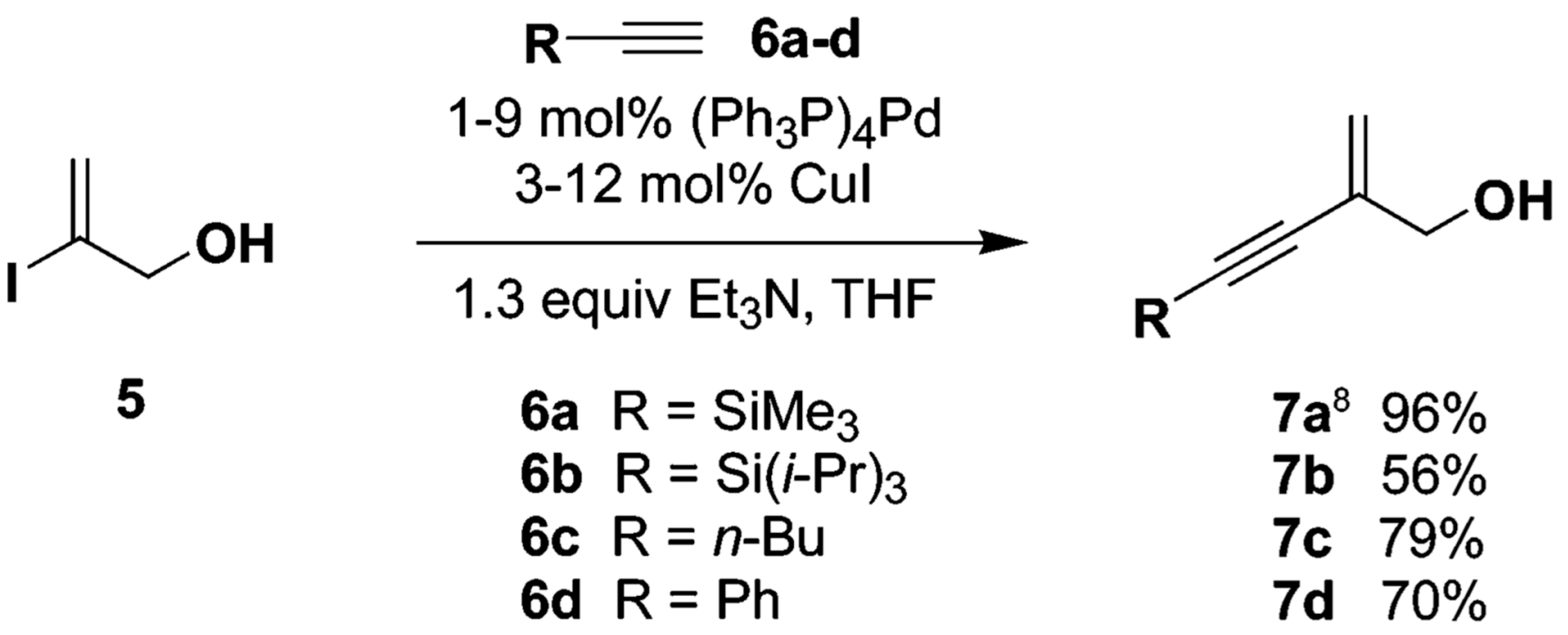

1a $52-53 \%$

1b $78 \%$

1c $59 \%$

1d $41 \%$

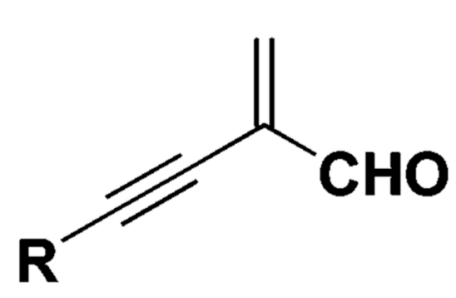

Dess-Martin periodinane

SCHEME 1. 

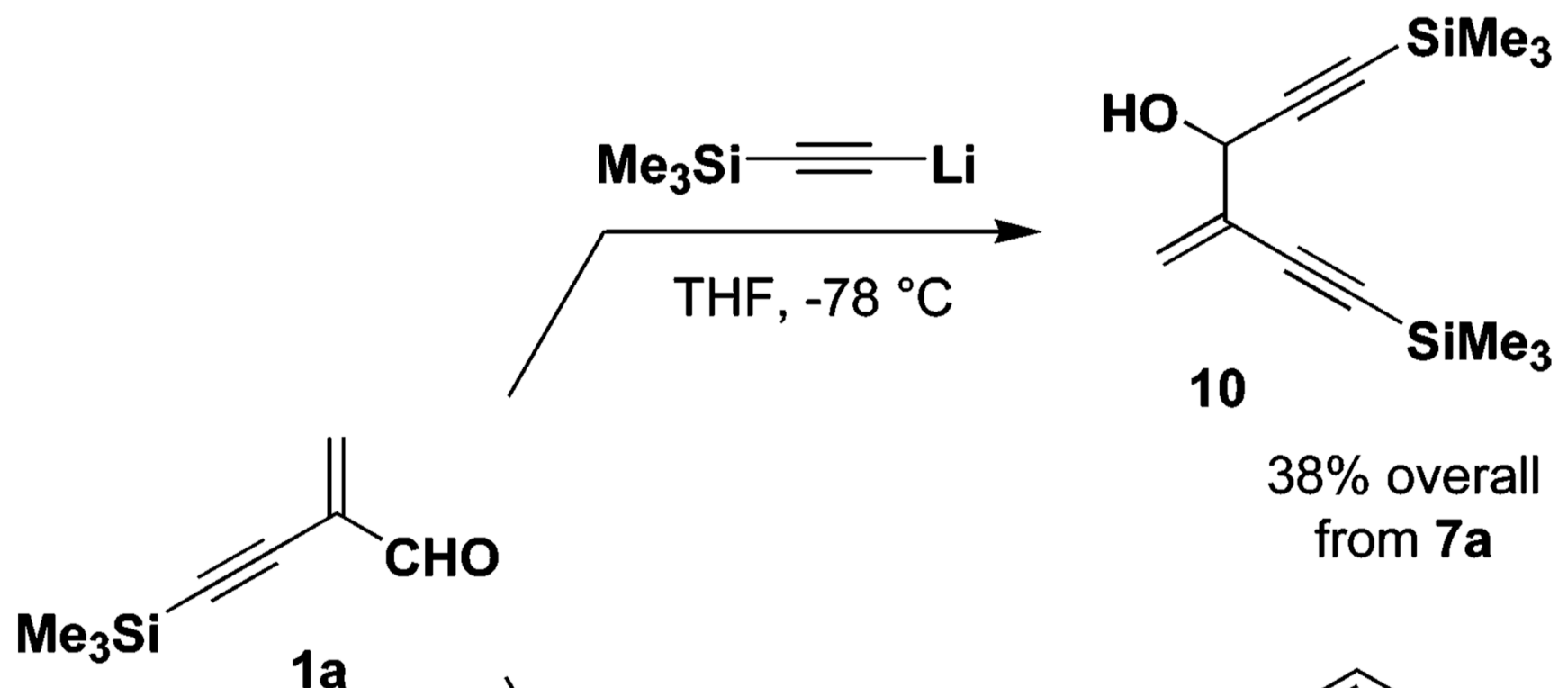

$38 \%$ overall from $7 a$

$1 \mathrm{a}$
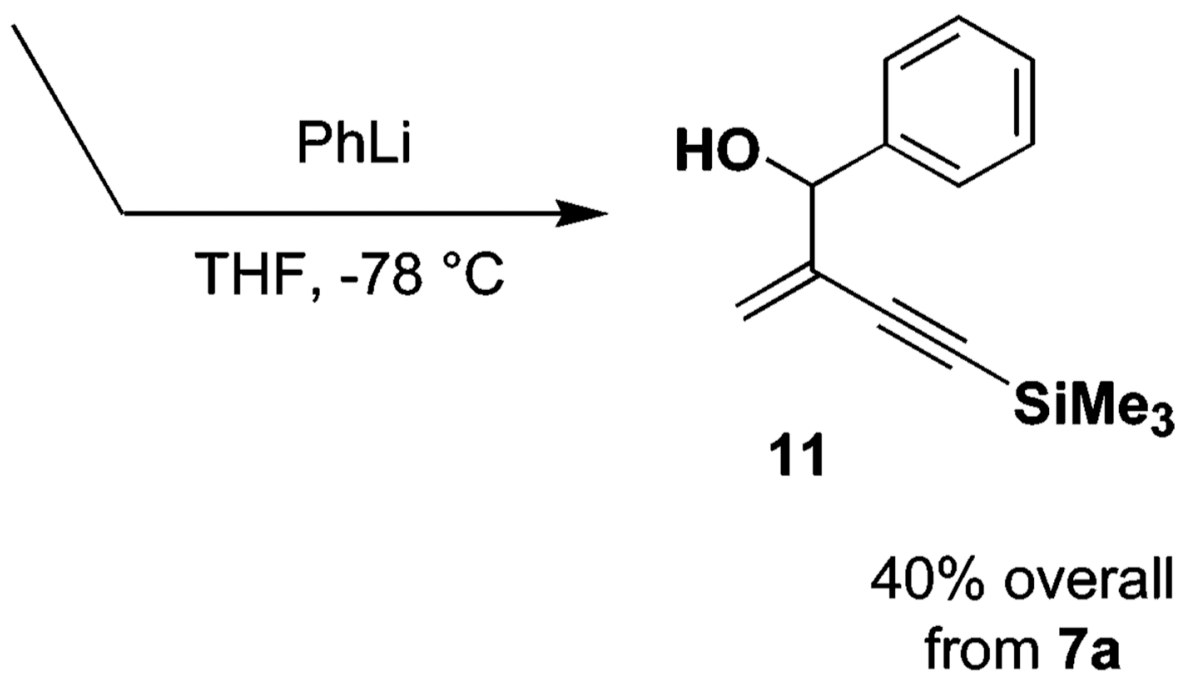

SCHEME 2. 